\title{
Stage Ois Bladder Cancer AJCC v8
}

National Cancer Institute

\section{Source}

National Cancer Institute. Stage Ois Bladder Cancer A/CC v8. NCI Thesaurus. Code C140418.

Stage Ois includes: T is, N0, M0. T is: Urothelial carcinoma in situ: "flat tumor". N0: No regional lymph node metastasis. M0: No distant metastasis. (AJCC 8th ed.) 